\title{
Collagenase and other proteinases in the cornea of the retinol-deficient rat
}

\author{
By ANTOINETTE PIRIE*, ZENA WERB AND MARY C. BURLEIGH \\ Strangeways Research Laboratory, Wort's Causeway, Cambridge $C B_{1}{ }_{4} R N$
}

(Received 13 fanuary 1975 - Accepted in March 1975)

1. Enzymes that may contribute to liquefaction of the cornea in retinol-deficient animals and in man have been studied using rat cornea. The established technique of culturing tissue fragments and determining the activity of collagenase $\left(E C_{3} .4 .24 .3\right)$ and other enzymes in the medium after different periods of culture was used.

2. A collagenolytic system was detected in the media from cultures of rat corneas. This system probably consists of at least two enzymes, a collagenase and a neutral proteinase.

3. Both proteolytic and specific collagenolytic activity were greater in media from retinoldeficient rat corneas. The hydroxyproline level increased in parallel with the increase in enzyme activity.

4. In the final stages of retinol deficiency the cornea is invaded by granulocytes and other cells of the blood and we suggest that destruction of cornea collagen may be due largely to the activity of the enzymes from these cells.

Severe retinol deficiency leads to destruction of the cornea through its liquefaction. The first clinically observed corneal change is dryness of the epithelium, and this may be followed by oedema of the stroma, keratinization of the epithelium, ulceration, and finally, perforation of the cornea. This severe form is found mainly in children who are seriously malnourished, but the syndrome can be reproduced in rats deficient only in retinol.

Collagenase $\left(E C C_{3} \cdot 4 \cdot 24 \cdot 3\right)$ is secreted into the medium during culture of the normal cornea from several species, including man, and is increased in amount in corneas that are ulcerating. The enzyme is like that from most other mammalian tissues in that it cleaves the $\alpha$-chains in the triple helix of the collagen molecule into fragments three-quarters and one-quarter its length, and is inhibited by metal chelators such as ethylenediaminetetraacetic acid (EDTA). Some success in treating ulcers in both human and animal corneas has been obtained by the topical use of collagenase inhibitors, and this has reinforced the concept that collagenase plays an important part in the development of ulcers of the cornea. Lemp (1974) has recently reviewed both experimental and clinical aspects of the subject.

We have studied collagenase and other neutral proteinases in the cornea of the normal and the retinol-deficient rat to determine whether these enzymes are involved in this particular type of cornea ulceration. We have used the rat because severe lesions of the cornea resulting from a lack of retinol are more easily produced in this species than in other laboratory animals.

* Present address: Nuffield Laboratory of Ophthalmology, Walton Street, Oxford OX2 6AW. 


\section{EXPERIMENTAL}

Animals and diets

Diets. The retinol-deficient diet (Moore \& Holmes, r97I) contained (g/kg): 800 plain white flour (Spillers Homepride; Spillers-French Baking Ltd, I80 High Holborn, London WCI $7 \mathrm{AB}$ ), I 50 dried yeast (English Grains Ltd, Overseal, Burton-on-Trent) and $5^{\circ}$ arachis oil (Evans Medical Ltd, Speke, Liverpool). The arachis oil contained $60 \mathrm{mg} \alpha$-tocopherol (British Drug Houses, Poole, Dorset), I.03 mg cholecalciferol (Sigma (London) Chemical Co. Ltd, Kingston on Thames, Surrey KT2 $7^{\mathrm{BH}}$ ) and, as preservative, $30 \mathrm{mg}$ butylated hydroxytoluene/1. The dry diet was moistened with water and minced (extrusion diameter $9.5 \mathrm{~mm}$ ). The extruded rods were air-dried and broken into a convenient length for feeding. Both food and water were freely available.

The composition of the diet containing retinoic acid was that described by Moore 8 Holmes (1971). The retinoic acid was dissolved in arachis oil, and added to the diet to give $5 \mathrm{mg}$ retinoic acid $/ \mathrm{kg}$, providing the rats with about $50 \mu \mathrm{g}$ retinoic acid/d.

Production of retinol deficiency. Hooded rats of the Strangeways Laboratory strain were used. The dam was given the retinol-deficient diet as soon as the litter was born, or the young were given this diet at weaning. They were kept on this deficient diet until growth faltered and they were then given the diet containing retinoic acid. This diet maintained growth and the health of the cornea (Dowling \& Wald, r960), but as retinoic acid is not stored in the body, signs of retinol deficiency appeared quickly when the rats were returned to the retinol-deficient diet, or given a diet of white bread which is retinol-free but is adequate in other respects over a short period of about 2 weeks. White bread is acceptable to the retinol-deficient animals because it is soft and easy to eat.

Eyes were examined with a loupe $\left(x_{10}\right)$ and torch to observe the early stages of corneal dryness and oedema. Later, 'naked-eye' examination was sufficient as there was a danger of causing perforation if the lids were held apart. The rats were weighed once per week.

\section{Materials}

Dulbecco's modification of Eagle's medium (DMEM; Io-fold stock concentrate) and foetal calf serum were purchased from Flow Laboratories Ltd, Irvine KAI 2 8NB, Scotland. The foetal calf serum was inactivated by heating at $56^{\circ}$ for $30 \mathrm{~min}$ before use. Tissue-culture Petri dishes were obtained from Sterilin Ltd, Richmond, Surrey. Crystamycin (Glaxo Laboratories Ltd, Greenford, Middx.) was used as an antibiotic.

Ultrafiltration was done using a Diaflo $5^{\circ}$ apparatus with a PM-1o membrane (Amicon Ltd, High Wycombe, Bucks.). The chemicals used were obtained from the following sources: chromatographically pure collagenase (from Clostridium histolyticum; grade CSPLA) from Cambrian Chemicals Ltd, Croydon, Surrey CRg 6AG; r,10-phenanthroline, soya-bean trypsin inhibitor (STI) and bovine serum albumin, crystalline, lyophilized, from Sigma (London) Chemical Co. Ltd, Kingston on Thames, Surrey $\mathrm{KT}_{2}{ }_{7} \mathrm{BH} ; 2,5$-phenyloxazole (PPO) (scintillation grade) from 
Packard Instruments Ltd, Caversham, Berks.; di-isopropylphosphorofluoridate (dip-F) from BDH Chemicals Ltd, Poole, Dorset; Coomassie Brilliant Blue R250 from G. T. Gurr, High Wycombe, Bucks.; [U_14 C]glycine from Radiochemical Centre, Amersham, Bucks.; Aquacide from Calbiochem Ltd, London WrH rAS; Sephadex G20o from Pharmacia (GB) Ltd, London W5. All other chemicals were commercially available analytical grade reagents.

\section{Culture methods}

The rats were killed by breaking the neck with a strong pair of pincers. This method was used to ensure rapid death without perforation of the corneas. The eyes were removed, the corneas excised immediately and placed in a sterile Petri dish, diameter $80 \mathrm{~mm}$, containing sterile DMEM buffered with sodium bicarbonate and containing glutamine $(200 \mathrm{mg} / \mathrm{l}$ ) and Crystamycin (400 units penicillin and $400 \mu \mathrm{g}$ strepromycin/ml). All corneas, usually six to ten/culture, were placed together in one dish, chopped roughly and washed three times with portions of the medium. After removing the last wash solution, the corneas were chopped into pieces about $2 \mathrm{~mm} \times$ $2 \mathrm{~mm}$ in size and transferred to a fresh Petri dish containing $\mathrm{r} \cdot \mathrm{O} \mathrm{ml}$ DMEM containing 200 units penicillin and $200 \mu \mathrm{g}$ streptomycin $/ \mathrm{ml}$. The culture was placed in a Mackintosh-Fildes anaerobic jar which was gassed thoroughly with carbon dioxide-nitrogenoxygen $\left(5: 75: 20\right.$, by vol), closed and placed in an incubator at $37^{\circ}$. The medium was changed each day or every other day for $7-9 \mathrm{~d}$ and the medium removed was then stored at $-20^{\circ}$. As much as possible of the work was done in a culture chamber sterilized using ultraviolet light. The sterility of the cultures was tested using nutrient broth or nutrient-agar plates. Media, combined from several cultures, were dialysed at $4^{\circ}$ using $5^{\circ} \mathrm{mm}$-Tris buffer, $\mathrm{pH} 7 \cdot 6$, containing $5 \mathrm{mM}^{-\mathrm{CaCl}_{2}}$, and concentrated either by ultrafiltration or by surrounding the dialysis sac with Aquacide or Sephadex G200.

\section{Histology}

The eyes were fixed either in saline $(9 \mathrm{~g} \mathrm{NaCl} / \mathrm{l})$ containing $100 \mathrm{ml}$ aqueous formaldehyde solution $(400 \mathrm{ml} / \mathrm{l}) / \mathrm{l}$, or in $12.5 \mathrm{~g}$ glutaraldehyde/l phosphate-buffered saline $\left(8 \mathrm{~g} \mathrm{NaCl}, 0 \cdot 2 \mathrm{~g} \mathrm{KH}_{2} \mathrm{PO}_{4}, \mathrm{I} \cdot 2 \mathrm{~g} \mathrm{Na}_{2} \mathrm{HPO}_{4} / 1\right)$ and embedded in paraffin. Sections were stained with haematoxylin and eosin.

\section{Assay procedures}

Substrates. Acid-soluble, rat-skin collagen and acid-soluble, rat-skin collagen labelled with [U.14 C]glycine were prepared using the methods described by Werb \& Burleigh (1974). The specific activity of the radioactive collagen was 7200 counts $/ \mathrm{min}$ per mg. Azocasein was prepared using the method of Charney \& Tomarelli (1947).

Assay of collagenase. Two methods were used; in the first method reconstituted fibrils were digested at $35^{\circ}$, at which temperature the collagenase cleavage products are denatured and become susceptible to further digestion; in the second method, collagen in solution was digested at $25^{\circ}$, which is below the temperature of denaturation of digestion products. 
Assay using reconstituted collagen fibrils. Collagenase activity was determined by the release of radioactive peptides from fibrils of reconstituted ${ }^{14} \mathrm{C}$-labelled rat-skin collagen at $35^{\circ}$, using the procedure described by Werb \& Burleigh (1974). One unit of collagenase activity is defined as the amount of enzyme which hydrolyses I $\mu \mathrm{g}$ collagen $(3.3 \mathrm{pmol}) / \mathrm{min}$ at $35^{\circ}$. Total lysis was determined using control tubes containing bacterial collagenase. The reaction mixtures were usually incubated for $20 \mathrm{~h}$. 'Control' mixtures containing ro $\mu \mathrm{g}$ trypsin were incubated also, to determine whether there was any denatured collagen in the preparation. Series of reaction mixtures in which the trypsin controls showed a release of more than $5 \%$ of the radioactivity above the "buffer' blanks were discarded.

Assay using collagen in solution. Acid-soluble, rat-skin collagen dissolved in $0^{\circ} \mathrm{I} \mathrm{M}-$ acetic acid was dialysed against a large volume of $0.1 \mathrm{M}$-Tris- $\mathrm{HCl}$ buffer, $\mathrm{pH} 8 \cdot 0$, containing $0.5 \mathrm{M}-\mathrm{NaCl}$ and $37.5 \mathrm{~mm}-\mathrm{CaCl}_{2}$. Aggregates were removed by centrifugation at $20000 \mathrm{~g}$ for $60 \mathrm{~min}$. Reaction mixtures containing the following final concentrations: $1.4 \mathrm{mg}$ collagen $/ \mathrm{ml}, 20 \mathrm{mM}-\mathrm{Tris}-\mathrm{HCl}$ buffer $(\mathrm{pH} 8.0), 0.4 \mathrm{M}-\mathrm{NaCl}$, $30 \mathrm{mM}-\mathrm{CaCl}_{2}$, enzyme, inhibitors and activators, in a final volume of $100 \mu \mathrm{l}$, were incubated at $25^{\circ}$ for $20 \mathrm{~h}$.

The products of enzymic digestion were analysed using disc-gel electrophoresis. The samples were denatured and the reaction stopped by addition of $5 \circ \mu \mathrm{l}$ of a solution containing $0.29 \mathrm{~g}$ sodium lauryl sulphate (SDS), 100 $\mu \mathrm{l}$ 2-mercaptoethanol, $\mathrm{I} \cdot 0 \mathrm{ml}$ bromophenol blue ( $\mathrm{g} / 1), 5 \mathrm{ml}$ glycerol, $2.5 \mathrm{ml}$ buffer (pH 8.4) (8.9 g boric acid, $19.86 \mathrm{~g}$ Tris $-\mathrm{HCl}, 4.0 \mathrm{~g}$ SDS/1), made up to $10 \mathrm{ml}$ with water. The denaturant solution and the sample were mixed well and incubated at $55^{\circ}$ for $30 \mathrm{~min}$.

Portions of the denatured samples were subjected to electrophoresis on polyacrylamide gels $(7 \circ \mathrm{mg} / \mathrm{ml})$ using the discontinuous buffer system containing SDS designed by Neville (1971).

Neutral proteinase. The activity of this enzyme was estimated at $37^{\circ}$ using azocasein as the substrate and a reaction mixture containing: $125 \mu \mathrm{l}$ azocasein $(60 \mathrm{~g} / \mathrm{l}), 125 \mu \mathrm{l}$ buffer ( $0.4 \mathrm{M}$-Tris, $\mathrm{pH} 7 \cdot 6$, containing: $80 \mathrm{mM}-\mathrm{CaCl}_{2}$ and sodium azide $(4 \mathrm{~g} / \mathrm{l})$ ), up to $250 \mu \mathrm{l}$ sample, and water to a final volume of $500 \mu \mathrm{l}$. The reaction was stopped by the addition of $2.5 \mathrm{ml}$ trichloroacetic acid (TCA) $(3 \circ \mathrm{g} / \mathrm{l})$, the mixture was filtered and the extinction at $366 \mathrm{~nm}$ of the filtrate was determined. A blank containing substrate without enzyme was included.

Proteoglycanase. The activity of this enzyme was estimated using the method of J. T. Dingle, A. J. Barrett \& M. J. Blow (personal communication).

Hydroxyproline. The amount of hydroxyproline in the culture medium was estimated using the method of Burleigh, Barrett \& Lazarus (1974).

Protein. The protein content of the culture medium was estimated using the method of Lowry, Rosebrough, Farr \& Randall (I95I), with standard solutions of bovine serum albumin.

Statistical analysis. Mean values with their standard errors are given unless otherwise indicated and the results were analysed using Student's $t$ test, or a modified $t$ test described by Bradford Hill (1971). 


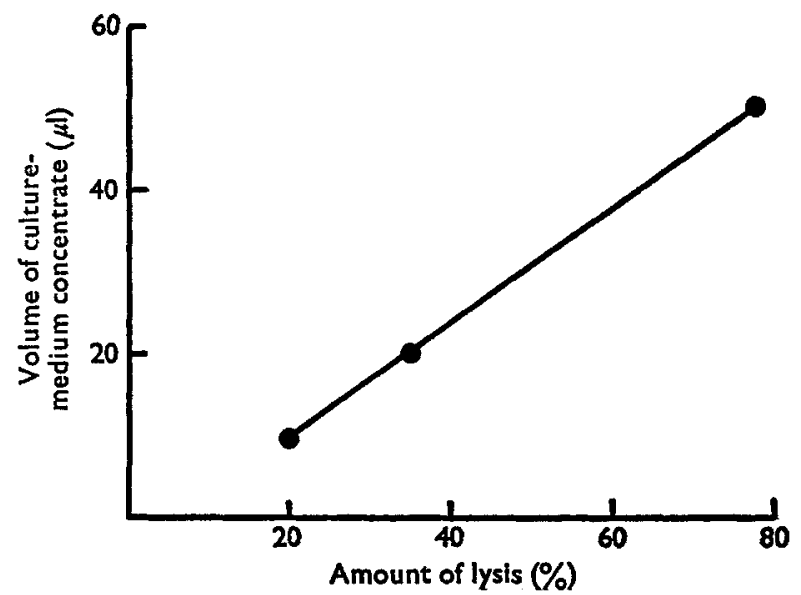

Fig. 1. Proportionality between the percentage lysis of reconstituted collagen fibrils and the volume of culture-medium concentrate in the digest. Concentrated medium from days 2 to 8 of culture of retinol-deficient corneas was used. Lysis was estimated from the release of radioactivity from ${ }^{14} \mathrm{C}$-labelled rat-skin collagen fibrils. For details of procedures, see p. 300 .

\section{RESULTS}

\section{Collagenase activity in cultures of corneas from normal and retinol-deficient rats}

Collagenase activity was estimated by measuring release of radioactive peptides from reconstituted fibrils of $\left[{ }^{14} \mathrm{C}\right]$ collagen from rat skin at $35^{\circ}$ (Werb \& Burleigh, 1974). The activity in the unconcentrated medium was low but all twenty-one cultures of retinol-deficient corneas showed some activity above that of the trypsin control whereas only six of the twelve cultures of normal cornea did so. Concentrates of culture media were therefore prepared; different cultures were combined for this purpose. The media from day $I$, days 2-4, days $5-8$ and, for one group of cultures of retinol-deficient corneas the media from days $2-8$, were combined and concentrated. Fibril assays were done using six separate concentrates from cultures of normal and retinol-deficient corneas. As the number of corneas in the original cultures and the extent of concentration of the combined media obtained were not uniform the results in some of the tables are given as units of enzyme activity/ml unconcentrated medium normalized to contain ten corneas $/ \mathrm{ml}$. The lack of uniformity in cultures was due to the attempt to use retinol-deficient rats on the day when their corneas were severely affected but not perforated.

Fig. I shows that the percentage lysis of collagen fibrils with release of radioactive peptides into solution is proportional to the amount of culture concentrate tested. There was considerable variation in enzyme activity between concentrates made from cultures of both retinol-deficient and normal corneas, even when they were of the same day or period of culture and, although the results from the 'fibril' assay suggested that collagenase release was greatest during the early period of culture of retinoldeficient corneas and at a later period of culture of normal corneas, there were not sufficient values to give certainty of this. To answer the question whether there was 
Table I. Percentage amount of lysis* of reconstituted rat-skin collagen fibrils by concentrates of the medium $\uparrow$ from cultures of normal and retinol-deficient corneas

(Values for single estimations using $50 \mu \mathrm{l}$ samples of concentrated media, twelve to sixteen corneas $/ \mathrm{ml}$ )

\begin{tabular}{|c|c|c|}
\hline \multirow[b]{2}{*}{ Period of culture } & \multicolumn{2}{|c|}{ Lysis (\%) } \\
\hline & $\begin{array}{l}\text { Normal } \\
\text { cornea }\end{array}$ & $\begin{array}{l}\text { Retinol-deficient } \\
\text { cornea }\end{array}$ \\
\hline Day I & $I \cdot 5$ & $4 I$ \\
\hline Days 2-4 & $x \cdot 6$ & 100 \\
\hline Days 2-8 & nd & 78 \\
\hline Days 5-8 & 22 & I9 \\
\hline
\end{tabular}

nd, Not determined.

* Lysis was estimated from the release of radioactivity from ${ }^{14} \mathrm{C}$-labelled collagen; for details, see p. 300 .

$\dagger$ The culture medium was changed each day or every other day, and the medium removed was stored at $-20^{\circ}$. The media from several cultures were combined and concentrated by ultrafiltration or dialysis; for details, see p. 299.

any difference in total collagenase release between cultures of normal and of retinoldeficient corneas we have combined results of all assays for days $\mathrm{I}-8$ and analysed them statistically using a modified $t$ test (Bradford Hill, I97I).

For the six concentrates of medium from each type of culture, the units of collagenase activity released $/ \mathrm{ml}$ unconcentrated medium (ten corneas $/ \mathrm{ml}$ ), were $0.082 \pm$ 0.044 in cultures of normal corneas and $\mathrm{I} \cdot \mathrm{I} 9 \pm 0.420$ in cultures of retinol-deficient corneas $(P<0.05)$. The results suggest that the total release of collagenase was greater in the cultures of the retinol-deficient corneas than in those of the normal corneas.

The percentage lysis, estimated from the radioactivity released from ${ }^{14} \mathrm{C}$-labelled rat-skin collagen by concentrates of medium from cultures of normal and retinoldeficient corneas, is given in Table $\mathrm{I}$. These results were from experiments in which, for each particular day or period of days, the number of corneas $/ \mathrm{ml}$ culture-medium concentrate was similar from both types of culture, so that a direct comparison between collagenase activity at a particular stage of culture was possible. The high enzymic activity in the culture medium of the retinol-deficient corneas from day $I$ is particularly interesting and may be due to the presence of invading cells. There was a decrease in collagenase activity during the later stages of the culture period of the retinol-deficient corneas which was not noticeable in cultures of the normal corneas.

The nature of the collagen cleavage products in the corneal enzyme digests of reconstituted $\left[{ }^{14} \mathrm{C}\right]$ collagen fibrils was studied. After centrifugation to remove residual fibrils, the amount of radioactivity for a portion of the supernatant fraction was measured. TCA $(15 \circ \mathrm{g} / \mathrm{l})$ was added to a second portion and, after centrifugation, the amount of radioactivity in the supernatant fraction containing the TCA-soluble products was measured. Half the total radioactivity was found in the TCA-soluble fraction which consists of peptides with a molecular weight less than 5000 daltons (Harris \& Krane, 1972). Tokoro, Eisen \& Jeffrey (1972) found that extensively purified collagenase from rat skin degraded collagen fibrils to small peptides, more than 
Table 2. Effect of potential inhibitors of collagenase on lysis* of reconstituted rat-skin collagen fibrils by concentrates of the medium $\uparrow$ from cultures of normal and retinoldeficient corneas

(Mean values; no. of estimations given in parentheses)

\section{Compound}

Trisodium EDTA

Disodium-zinc EDTA

I, Io-Phenanthroline

Foetal calf serum

Di-isopropylphosphorofluoridate (dip-F)

Soya-bean trypsin inhibitor (STI)

Conc. in reaction
medium
$20 \mathrm{mM}$
$20 \mathrm{mM}$
$1 \mathrm{mM}$
$50 \mu \mathrm{l} / \mathrm{ml}$
$1 \mathrm{mM}$
$1 \mathrm{mg} / \mathrm{ml}$

\begin{tabular}{|c|c|}
\hline \multicolumn{2}{|c|}{ Inhibition (\%) } \\
\hline $\begin{array}{l}\text { Normal } \\
\text { cornea }\end{array}$ & $\begin{array}{c}\text { Retinol-deficient } \\
\text { cornea }\end{array}$ \\
\hline $\begin{array}{c}87 \text { (4) } \\
\text { nd } \\
84(4) \\
\text { nd }\end{array}$ & $\begin{array}{r}85(4) \\
0(\mathrm{I}) \\
100(4) \\
100(\mathrm{I})\end{array}$ \\
\hline $\begin{array}{l}39(1) \\
38(2)\end{array}$ & $\begin{array}{l}30(4) \\
\text { I7 (3) }\end{array}$ \\
\hline
\end{tabular}

nd, Not determined; EDTA, ethylenediaminetetraacetate.

* Lysis was estimated from the release of radioactivity from ${ }^{14} \mathrm{C}$-labelled collagen; for details, see p. 300 .

$\dagger$ The culture medium was changed each day or every other day, and the medium removed was stored at $-20^{\circ}$. The media from several cultures were combined and concentrated by ultrafiltration or dialysis; for details, see p. 299.

$60 \%$ of which were dialysable. Thus the enzyme system from the cornea and collagenase from the skin degrade collagen to a similar extent.

Substances known to inhibit other mammalian collagenases or other proteinases were tested using the corneal system which lysed collagen fibrils. The results given in Table 2 indicated that fibril lysis was almost completely inhibited by the metal chelators EDTA and 1,10-phenanthroline, but not by disodium-zinc EDTA. It was also inhibited by foetal calf serum, presumably due to the $\alpha_{2}$-macroglobulin it contains. This inhibits all classes of proteinase (Werb, Burleigh, Barrett \& Starkey, 1974). STI and dip-F, which inhibit 'serine' proteinases, affect the corneal collagenase system only slightly. It is possible that these two compounds inhibit a proteinase, acting as a 'helper' enzyme for collagenase, as suggested by Lazarus, Daniels, Lian \& Burleigh ( 1972 ) for the collagenase system of human granulocytes. The enzymes from normal and retinol-deficient corneas reacted similarly to the potential inhibitors, at all stages of culture.

Compounds that block thiol groups activate some mammalian collagenases (Werb \& Burleigh, I974) but addition of $\mathrm{I} \cdot 0 \mathrm{mM}-4$-chloromercuribenzoate had no effect on lysis of collagen fibrils by the collagenase system of the cornea. It is possible that the preparations were too crude for a significant reaction to take place between the potential activator and the enzyme, or possibly the enzymes of the rat differ from those of other animals in this respect.

A further experiment was done to determine whether, before culturing, collagenase is attached to the collagen fibres of the cornea. The two corneas of a normal rat and those from a retinol-deficient rat were removed and washed separately in DMEM containing 400 units penicillin and $400 \mu \mathrm{g}$ streptomycin $/ \mathrm{ml}$. They were then chopped roughly and ground as finely as possible in small plastic centrifuge tubes using a plastic rod, $0.2 \mathrm{ml} \circ \cdot 1 \mathrm{M}$-Tris, $\mathrm{pH} 7 \cdot 6$, containing $5 \mathrm{mM}^{-\mathrm{CaCl}_{2}}$ was added during 


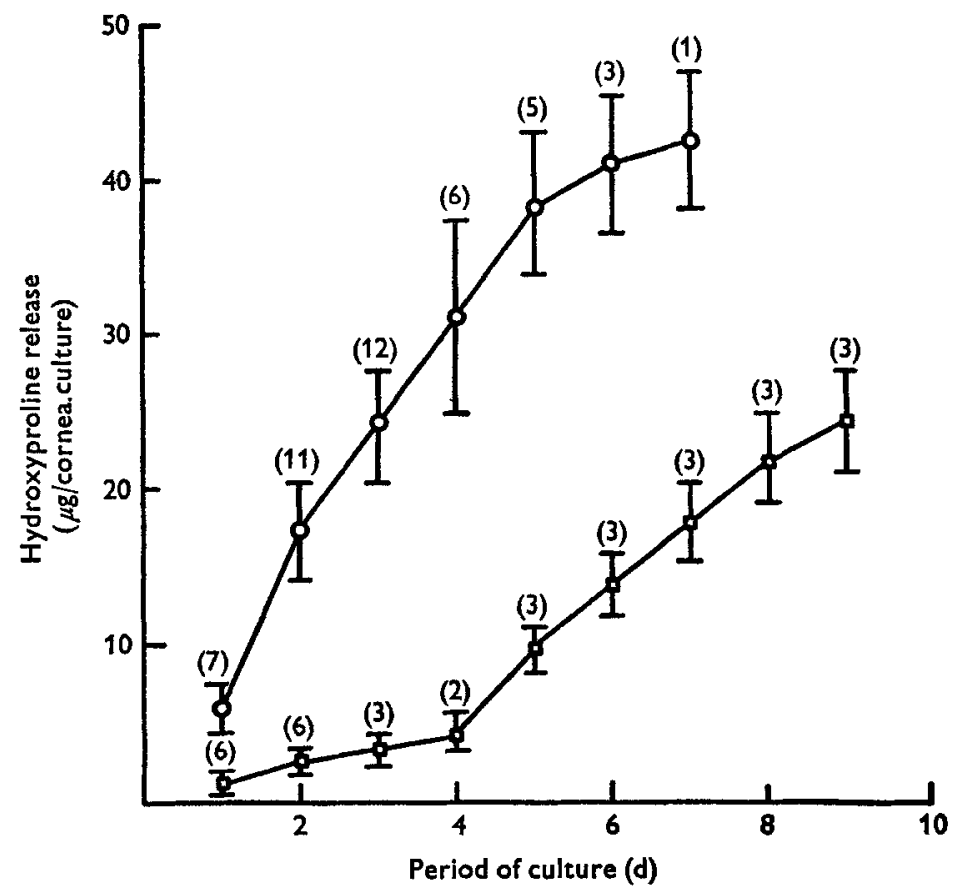

Fig. 2. Cumulative release of hydroxyproline ( $\mu \mathrm{g} /$ cornea per culture) into the medium of cultures of normal and retinol-deficient corneas. The culture medium was changed each day and the medium removed was stored at $-20^{\circ}$. For details of procedures, see p. 299. $\square$, Normal cornea; $O$, retinol-deficient cornea. The points represent mean values, with their standard errors represented by vertical bars; the nos. of individual cultures are given in parentheses. The statistical significance of the differences between the mean values for the cumulative release of hydroxyproline ( $\mu \mathrm{g} /$ cornea per culture) for the normal and the retinoldeficient cultures were: day I $P<0.02$, day $2 P<0.005$, day $3 P<0.01$, day $4 P<0.1$, day $5 P<0.005$, day $6 P<0.005$, days $\mathrm{I}-7$ combined $P<0.001$.

grinding. The slurries were then centrifuged at I I $600 \mathrm{~g}$ for to $\mathrm{min}$, the supernatant fractions were removed and the pellets of insoluble collagen suspended in $0.2 \mathrm{ml}$

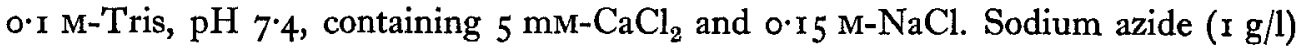
was added and the tubes incubated at $37^{\circ}$ for $72 \mathrm{~h}$. Undigested collagen was removed by centrifugation and the amount of hydroxyproline in acid-hydrolysates of the supernatant fractions was estimated. No hydroxyproline was present in the supernatant fraction from the normal corneas but $9.6 \mu \mathrm{g}$ was present in that from the retinol-deficient corneas. Thus a small amount of collagenase appears to be attached to the collagen fibres of the cornea of the retinol-deficient rat. In this experiment no hydroxyproline was found in the supernatant fraction from the insoluble collagen of either type of cornea before incubation.

\section{Hydroxyproline release into culture medium}

The tissue fragments in the cultures of the retinol-deficient rat corneas became smaller and more fragile as the culture period proceeded, whereas the fragments of normal rat corneas retained their firmness. Since the cornea consists very largely of 
collagen, endogenous substrate was available for any collagenase present. Release of soluble hydroxyproline-containing peptides into the medium was estimated for each day of culture. As the medium did not contain ascorbate no synthesis of collagen took place. The medium was centrifuged to remove fragments of tissue and cells before sampling. Fig. 2 shows the cumulative release of hydroxyproline $(\mu \mathrm{g} / \mathrm{cornea}$ per $\mathrm{d}$ of culture) into the culture medium. The results shown in Fig. 2 indicated that significant digestion of corneal collagen had taken place in the cultures. The rate of release in cultures of retinol-deficient corneas was greatest on days $\mathrm{I}-4$ and became negligible after day 5. On the other hand, the medium from cultures of normal corneas contained little hydroxyproline until day 5 of the culture period when release of hydroxyproline began. This difference will be discussed later. The large values for standard errors for hydroxyproline assays of media from cultures of retinol-deficient corneas may have arisen from the inevitable differences in the pathological state of these corneas, which were necessarily removed at different stages of retinol deficiency.

The wet weight of the rat cornea was about $4 \mathrm{mg}$ and the dry weight was $\mathrm{x} \cdot 35 \mathrm{mg}$. The collagen content of the mammalian cornea is $750 \mathrm{mg} / \mathrm{g}$ dry weight and, on this basis, each rat cornea contained approximately $\mathrm{x}$ mg collagen. Rat-cornea collagen is the same type as rat-skin collagen (Davison \& Berman, 1973) which contains I25-130 mg hydroxyproline/g. Calculating from this value, the cumulative digestion of collagen in the culture of cornea from the retinol-deficient rat up to and including day 4 was, on average, $25 \%$ compared with $3 \%$ in the culture of the normal cornea during the same period.

\section{Digestion of collagen in solution}

Collagenase isolated from the tissues of man and most other mammals cleaves the helical part of the collagen molecule characteristically into fragments three-quarters and one-quarter its length. But collagenase isolated from tissues of the rat produces multiple fragments from native collagen in solution, as shown by polyacrylamide gel electrophoresis (Jeffrey \& Gross, 1970; Tokoro et al. 1972).

The collagenase system extracted from the cultures of corneas of both normal and retinol-deficient rats gave products which followed the same pattern. Digests of ratskin collagen in solution at neutral $\mathrm{pH}$ and $25^{\circ}$ produced multiple bands when they were subjected to electrophoresis on polyacrylamide gels. Plate I shows typical results. There was no qualitative difference between enzyme preparations from normal and retinol-deficient corneas. Digestion was inhibited completely by $\mathrm{I} \cdot \mathrm{O} \mathrm{mM}-\mathrm{I}, \mathrm{IO}-$ phenanthroline, by 10-30 mM-EDTA and by ro mM-cysteine. It was not affected by I $\mathrm{mg} \mathrm{STI} / \mathrm{ml}$ or I $\mathrm{mg} \operatorname{dip}-\mathrm{F} / \mathrm{ml}$ or I $\mathrm{mM}-\mathrm{N}$-acetyl cysteine.

Thus STI had no apparent inhibitory effect on digestion of collagen in solution at $25^{\circ}$ but did inhibit collagen fibril lysis at $35^{\circ}$ by $17 \%$. This lack of effect of STI on the disc-gel electrophoresis patterns may have been because, in general, digestion was continued for $20-24 \mathrm{~h}$ in order to detect even weak enzyme activity. In one experiment, samples of the digests were taken after short time intervals and, as digestion proceeded, the pattern became more complex; multiple bands appeared after $\mathrm{I} h$ digestion. 
Table 3. Neutral proteinase activity in concentrates of the medium* from cultures of normal and retinol-deficient corneas

(Mean values with their standard errors; no. of estimations given in parentheses)

\begin{tabular}{|c|c|c|c|c|c|}
\hline \multirow[b]{3}{*}{ Period of culture } & \multicolumn{4}{|c|}{ Activity (Units $+/ \mathrm{ml}$ unconcentrated medium $\dagger$ ) } & \multirow{3}{*}{$\begin{array}{c}\text { Significance of } \\
\text { difference between } \\
\text { groups: } \\
\boldsymbol{P}\end{array}$} \\
\hline & \multicolumn{2}{|c|}{ Normal cornea } & \multicolumn{2}{|c|}{$\begin{array}{l}\text { Retinol-deficient } \\
\text { cornea }\end{array}$} & \\
\hline & Mean & SE & Mean & $\mathrm{SE}$ & \\
\hline $\begin{array}{l}\text { Day I } \\
\text { Days } 2-4\end{array}$ & $\begin{array}{l}0 \\
0.71\end{array}$ & $\begin{array}{r}(1) \\
0.046(3)\end{array}$ & $\begin{array}{l}0.54 \\
4.9\end{array}$ & $\begin{array}{r}(1) \\
0.888(2)\end{array}$ & $<0.01$ \\
\hline $\begin{array}{l}\text { Days } 2-8 \\
\text { Days } 5-8\end{array}$ & $\begin{array}{l}\text { nd } \\
2 \cdot 07\end{array}$ & $0.224(3)$ & $\begin{array}{l}6 \cdot 7 \\
2 \cdot 99\end{array}$ & $\begin{array}{l}0.89(4) \\
0.555(2)\end{array}$ & $<0.2$ \\
\hline $\begin{array}{l}\text { nd, Not determ } \\
\text { The culture } \\
\text { stored at }-20^{\circ} \text {. T } \\
\text { dialysis; for detail } \\
\dagger \text { One unit of } \mathrm{e} \\
\text { tion at } 366 \mathrm{~nm} \text { of } \\
\ddagger \text { As the no. of } \\
\text { given as units of }\end{array}$ & $\begin{array}{l}\text { change } \\
\text { m sever } \\
\text { ty is def } \\
\text { For de } \\
\text { are and } \\
\text { ty } / \mathrm{r} \cdot 0 \mathrm{~m}\end{array}$ & $\begin{array}{l}\text { ach day o } \\
\text { ultures we } \\
\text { d as that a } \\
\text { s of estima } \\
\text { extent of c } \\
\text { nconcentr? }\end{array}$ & $\begin{array}{l}\text { ry oth } \\
\text { mbine } \\
\text { t of en } \\
\text { proced }\end{array}$ & $\begin{array}{l}\text { ay, and th } \\
\text { id concent } \\
\text { see that proc } 300\end{array}$ & $\begin{array}{l}\text { medium removed wa } \\
\text { ed by ultrafiltration } \\
\text { ces a change in extinc }\end{array}$ \\
\hline
\end{tabular}

\section{Neutral proteinase activity in concentrates of culture media}

The cornea contains soluble proteins and proteoglycans and it has been suggested by Gnadinger, Itoi, Slansky \& Dohlman (1969) that, in vivo, removal of these compounds facilitates digestion of collagen. Proteinase activity was determined, using azocasein as the substrate, at $\mathrm{pH} 7 \cdot 6$. The buffer contained $\mathrm{I} g$ sodium azide/ 1 to prevent bacterial growth. An active proteinase was found to be present, particularly in the concentrates of media from cultures of retinol-deficient corneas (Table 3 ) and, as with collagenase, the enzyme was most active in the early days of culture whereas the concentrated medium from cultures of normal corneas was more active after $5 \mathrm{~d}$.

Tests of potential inhibitors showed that the proteinase of both normal and retinoldeficient corneas was inhibited by the same substances that inhibited corneal collagenase. The most potent inhibitors were the metal chelators (EDTA and 1,10-phenanthroline). It is possible that inhibitors of 'serine' proteinases (dip-F and STI) were more effective inhibitors of corneal proteinase than of collagenase but it has not yet been possible to distinguish between the two enzymes by use of inhibitory substances (Table 4).

\section{Proteoglycanase activity in concentrates of culture media}

An enzyme or enzymes in the culture media digested ${ }^{35} \mathrm{~S}-$ labelled bovine nasal cartilage proteoglycan at neutral $\mathrm{pH}$. The concentrated media from normal corneal cultures showed little enzyme activity whereas those from retinol-deficient corneas hydrolysed $19-39 \%$ of the substrate. The substrate incubated without enzyme released between 3 and $6 \%$ of the total radioactivity. 
Table 4. Effect of potential inhibitors on the activity of the neutral proteinase* in concentrates of the medium $\uparrow$ from cultures of normal and retinol-deficient corneas

(Mean values; no. of estimations given in parentheses)

\begin{tabular}{|c|c|c|c|}
\hline \multirow[b]{2}{*}{ Compound } & \multirow[b]{2}{*}{$\begin{array}{l}\text { Conc. in reaction } \\
\text { medium }\end{array}$} & \multicolumn{2}{|c|}{ Inhibition $(\%)$} \\
\hline & & $\begin{array}{l}\text { Normal } \\
\text { cornea }\end{array}$ & $\begin{array}{l}\text { Retinol-deficient } \\
\text { cornea }\end{array}$ \\
\hline $\begin{array}{l}\text { Trisodium EDTA } \\
\text { I,ro-Phenanthroline } \\
\text { Cysteine } \\
\alpha_{2}-\text { Macroglobulin from foetal calf serum } \\
\text { Di-isopropylphosphorofluoridate } \\
\text { Soya-bean trypsin inhibitor }\end{array}$ & $\begin{array}{l}\text { 10 } \mathrm{mM} \\
0.6 \mathrm{mM} \\
\text { 10 } \mathrm{mM} \\
\text { I } \mathrm{mg} / \mathrm{ml} \\
\text { I } \mathrm{mM} \\
\text { I } \mathrm{mg} / \mathrm{ml}\end{array}$ & $\begin{array}{l}100(1) \\
100(2) \\
100(2) \\
90(2) \\
52(2) \\
41(2)\end{array}$ & $\begin{array}{l}86(3) \\
90(2) \\
79(2) \\
83(4) \\
68(4) \\
39(2)\end{array}$ \\
\hline \multicolumn{4}{|c|}{$\begin{array}{l}\text { EDTA, ethylenediaminetetraacetate. } \\
\text { * For details of procedures, see p. } 300 \text {. } \\
\dagger \text { 'The culture medium was changed each day or every other day and the medium removed was } \\
\text { tored at }-20^{\circ} \text {. The media from several cultures were combined and concentrated by ultrafiltration or } \\
\text { lialysis; for details, see p. } 299 \text {. }\end{array}$} \\
\hline
\end{tabular}

\section{Cell content of the corneal cultures}

Examination of unfixed, unstained corneal cultures at the end of the culture period showed that although isolated cell clumps and cells round the corneal fragments were present in cultures of normal rat corneas, there were few healthy cells in cultures of retinol-deficient corneas. The cells seen in the normal cultures were mainly small round cells with a large nucleus, together with a few clumps of large cells with a relatively small nucleus. It was rare to observe any cell that could be called a fibrocyte.

Development of the lesion in the retinol-deficient rat proceeds from an initial change in the epithelium to stromal oedema so severe that when the cornea was excised, it retained its shape and curvature whereas the normal cornea collapsed. These changes were followed by infiltration of the corneal stroma by leucocytes, mainly granulocytes. This infiltration was accompanied by peripheral vascularization and ulceration, and terminally, patches of the cornea, sometimes the whole periphery, were yellow-white and perforation was inevitable.

Sections of the retinol-deficient cornea illustrate these changes (Plate 2), and at the severe stage of xerophthalmia which we aimed to use in culture, the sections showed that there had been a massive infiltration of granulocytes and other cells into the corneal stroma. In culture, granulocytes are not viable, so that enzymes from these cells could only contribute during the first few days to any enzymic activity found in medium from cultures of retinol-deficient corneas.

\section{DISCUSSION}

The collagenolytic system we have described in the cornea of the rat has not been characterized as a typical mammalian collagenase. We have not attempted, because of the shortage of material and because multiple cleavage products are rapidly formed, to prepare the characteristic three-quarter and one-quarter cleavage products of the 
helical part of the collagen molecule in the form of segment-long spacing aggregates. We therefore refer to the enzyme as a 'collagenase' for convenience only.

Tokoro et al. (1972) were able to separate the collagenase of rat skin from the accompanying proteinase and found that the purified enzyme still formed multiple cleavage products from native collagen at $25^{\circ}$. In this respect the enzyme from rat skin is unlike any other mammalian collagenase (Harris \& Krane, 1974). The collagenolytic system in the medium of cultures of rat cornea also formed multiple cleavage products from native collagen at $25^{\circ}$, but we have no evidence to decide whether or not this was due to the activity of one specific collagenase or whether the neutral proteinase also took part. Separation of proteinase from collagenase in the medium was not attempted. Both enzymes appeared to be metal enzymes and were inhibited by the same range of substances. The partial inhibition of azocasein digestion by dip-F and STI suggests that a 'serine' proteinase, possibly elastase (EC $3 \cdot 4 \cdot 2$ I. II), may also be present.

A further complexity in determining the type and source of the enzymes involved in digestion of corneal collagen is that the cornea of the retinol-deficient rat becomes heavily infiltrated by leucocytes, mainly granulocytes, and the enzymes of these invading cells may be crucial. A specific collagenase as well as a neutral proteinase has been found in the granulocytes of man (Lazarus et al. 1972).

Digestion of collagen, as evidenced by release of hydroxyproline-containing peptides into the medium, is greatest on day 2 of the culture of retinol-deficient corneas whereas digestion is negligible until day 5 of culture of the normal corneas (Fig. 2). There is also greater proteinase activity on day $\mathrm{I}$ and days $2-4$ of culture of retinoldeficient corneas than for normal corneas during the same period (Table 3 ). It seems possible that granulocyte collagenase and proteinase are responsible for some or all enzymic activity found at the early stage of culture of the retinol-deficient cornea. Although granulocytes are not viable, the collagenase they contain can be released by cell lysis without the need for cell growth in culture (Lazarus, Brown, Daniels \& Fullmer, 1968) and therefore might be expected to be present in the culture medium during the early stage of culture.

There are many reports of the invasion of the wounded or burned cornea by granulocytes. Weimar (1957) found that polymorphs invaded the cornea of the rat within 5 h of sustaining a central wound. Brown \& Hook (197I) suggest that polymorphs are the source of stromal collagenase in ulcerating cornea, and Lemp (1974) suggests that the frequency of ulceration in eyes with severe limbal damage may reflect the longer time for revascularization, which allows granulocytes to migrate into the cornea well in advance of new vessels.

Kuming \& Politzer ( 1967 ) have published a microphotograph of a section of cornea from the eye of a retinol-deficient child. This shows that there has been a massive cell infiltration of the stroma similar to that seen in the cornea of the retinol-deficient rat. The clinical reports of xerophthalmia describe dryness of the conjunctiva and of the cornea, oedema of corneal stroma and finally a 'cheesy' appearance before 'liquefaction'. These stages seem to correspond with those we have observed in the eye of the retinol-deficient rat. Possibly it is not only enzymes within the cornea that must 
British Fournal of Nutrition, Vol. 34, No. 2

Plate I

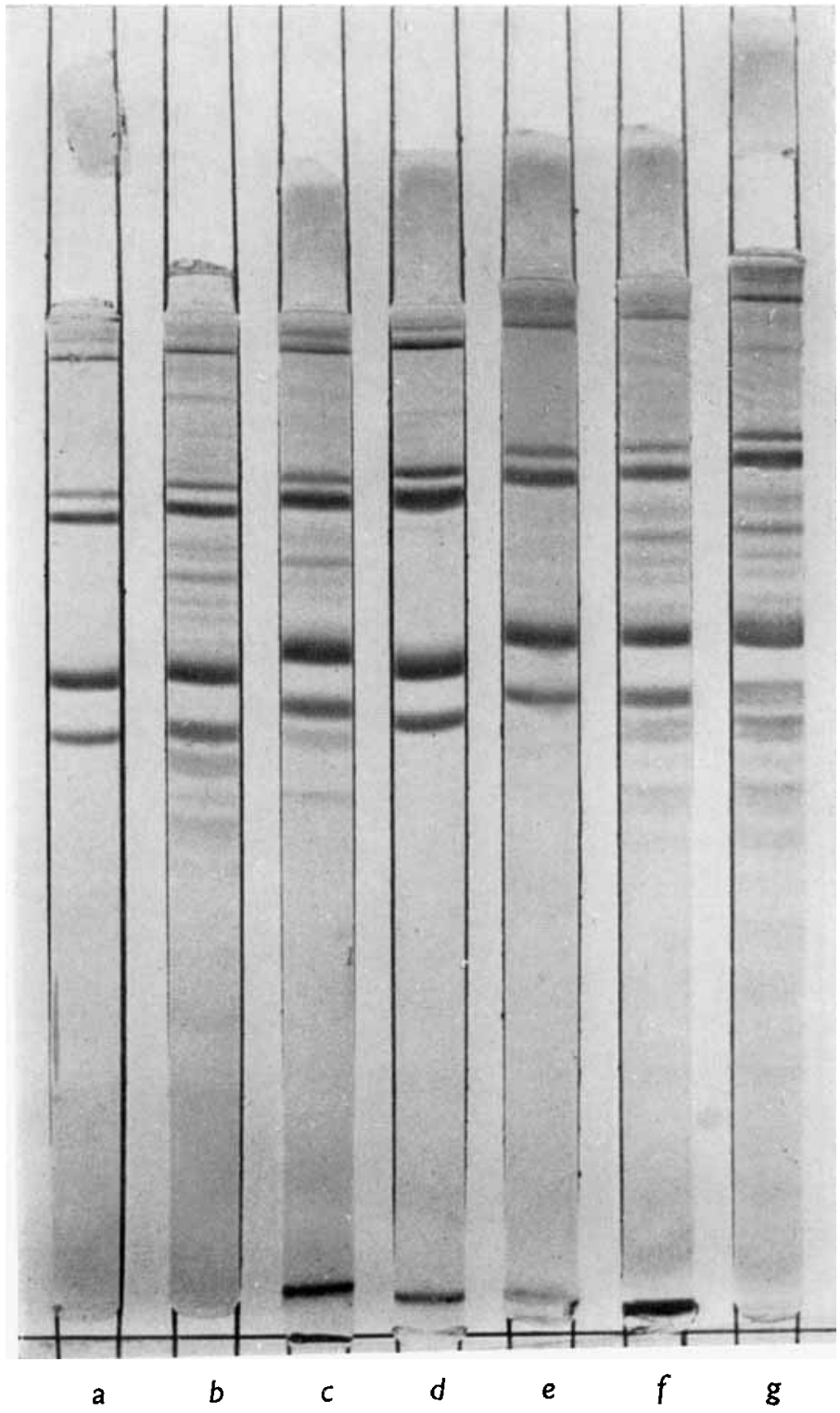

ANTOINETTE PIRIE, ZENA WERB AND MARY C. BURIEIGH

(Facing p. 308) 
British Fournal of Nutrition, Vol. 34, No. 2

Plate 2

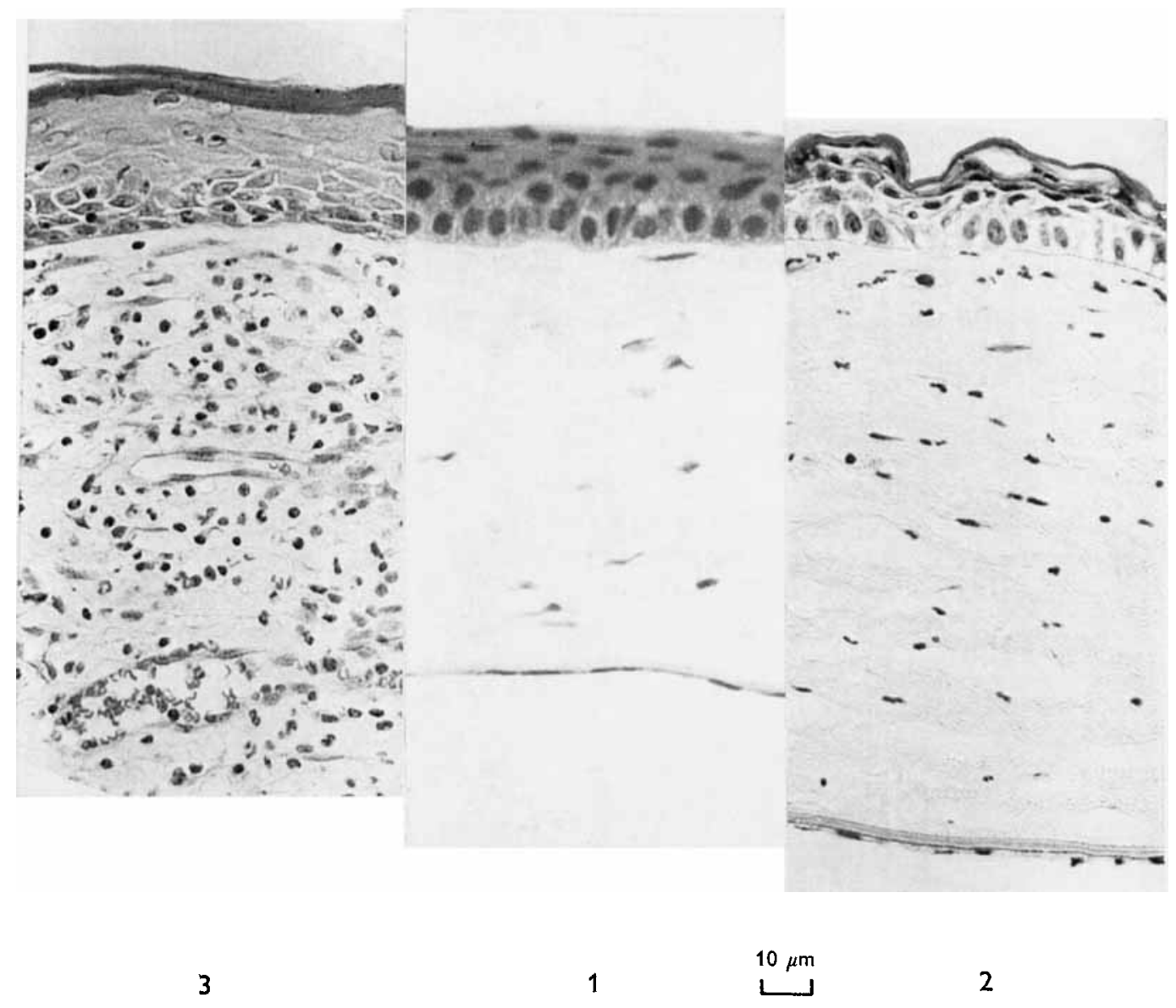

ANTOINETTE PIRIE, ZENA WERB AND MARY C. BURLEIGH 
be considered. Broomfield \& Brown (1974) have found that collagenase is produced by the inflamed conjunctiva, and we have found an active collagenase in the medium from cultures of the Harderian gland of the rat (unpublished results). The collagen of the retinol-deficient or of the wounded or burned cornea is at risk from all these sources of enzyme but, for the retinol-deficient cornea of rat and man it is possible that the greater danger comes from the enzymes of the invading cells.

The authors thank the Wellcome Trust, the Smith, Kline and French Foundation, the (UK) Medical Research Council and the Medical Research Council of Canada for their generous support, and they are indebted to their colleagues, in particular Dr J. T. Dingle and Dr T. Moore, for advice and help. A.P. also wishes to thank the Clothworkers' Company and Girton College, Cambridge, for the award of a Visiting Research Fellowship, and Mr M. Abercrombie for providing laboratory space. They also wish to thank Mr M. W. Stebbings for care of the animals and Mrs W. Beard and Mrs J. Muncy for their technical assistance.

\section{REFERENCES}

Bradford Hill, A. (1971). Principles of Medical Statistics, gth ed., ch. 6. London: The Lancet.

Broomfield, S. E. \& Brown, S. I. (1974). Invest. Ophthal. 13, 547.

Brown, S. I. \& Hook, C. W. (197I). Am. F. Opthal. 72, II 39.

Burleigh, M. C., Barrett, A. J. \& Lazarus, G. S. (1974). Biochem. F. 137, 387.

Charney, J. \& Tomarelli, R. M. (1947). F. biol. Chem. 171, 50r.

Davison, P. F. \& Berman, M. (1973). Connect. Tissue Res. 2, 57.

Dowling, J. E. \& Wald, G. (1960). Vitams Horm. 18, 515.

Gnadinger, M. C., Itoi, M., Slansky, H. H. \& Dohlman, C. H. (1969). Am. F. Ophthal. $68,478$.

Harris, E. D. \& Krane, S. M. (1972). Biochim. biophys. Acta 258, 566.

Harris, E. D. \& Krane, S. M. (1974). New Engl. F. Med. 29r, 605.

Jeffrey, J. J. \& Gross, J. (1970). Biochemistry, Easton 9, 268.

Kuming, B. S. \& Politzer, W. M. (rg67). Br. J. Ophthal. 5x, 648.

Lazarus, G. S., Brown, R. S., Daniels, J. R. \& Fullmer, H. M. (1968). Science, N.Y. 159, I483.

Lazarus, G. S., Daniels, J. R., Lian, J. \& Burleigh, M. C. (1972). Am. F. Path. 68, 565.

Lemp, M. A. (1974). Archs Ophthal., N.Y. 92, 158.

Lowry, O. H., Rosebrough, N. J., Farr, A. L. \& Randall, R. J. (195I). F. biol. Chem. 193, 265.

Moore, T. \& Holmes, P. D. (1971). Lab. Anim. 5, 239.

Neville, D. M. (1971). F. biol. Chem. 246, 6328.

Tokoro, Y., Eisen, A. Z. \& Jeffrey, J. J. (1972). Biochim. biophys. Acta 258, 289.

Weimar, V. (1957). F. exp. Med. 105, 14I.

Werb, Z. \& Burleigh, M. C. (r974). Biochem. F. 137, 373.

Werb, Z., Burleigh, M. C., Barrett, A. J. \& Starkey, P. (1974). Biochem. J. 139, 359.

\section{EXPLANATION OF PLATES}

\section{Plate I}

Disc-gel electrophoresis of the denatured products of hydrolysis of collagen in solution by concentrates of the medium from cultures of retinol-deficient corneas. Concentrated culture medium was incubated with rat-skin collagen in solution at $25^{\circ}$ for $20 \mathrm{~h}$. The polyacrylamide gel $(70 \mathrm{mg} / \mathrm{ml})$ and buffer system described by Neville (r97r) were used; for details of procedures, see p. 300. The incubation mixtures contained collagen and $(a)$ buffer only; $(b) 20 \mu \mathrm{l}$ culture concentrate (retinol-deficient corneas, days $2-8$ of culture); (c) $b$ plus N-acetyl cysteine (ro mM); (d) $b$ plus ethylenediaminetetraacetic acid ( $3 \circ \mathrm{mM}) ;(e) b$ plus I, IO-phenanthroline (1 $\mathrm{mM}) ;(f) b$ plus soya-bean trypsin inhibitor (I $\mathrm{mg} / \mathrm{ml}$ ); (g) $30 \mu 1$ culture concentrate.

\section{Plate 2}

Sections of normal cornea and of cornea at different stages of retinol deficiency in rats. (r) Normal cornea; (2) epithelial keratinization, stromal oedema and slight cell infiltration in cornea of retinoldeficient rat; (3) further stage of cell infiltration together with invasion of cornea by capillaries. 